\title{
Chewing gum town thematic park: Mayan social interactions at south state of Quintana Roo in Mexico
}

\begin{abstract}
Pueblo Chiclero or Chewing Gum Town is a Thematic Park, intended to be a replica of how people lived in this place at the beginning of the 20th century, built by people from Ejido Chacchoben in South State of Quintana Roo, with Federal and State money. The purpose was to receive tourist and to generate local employment. In this Park, tourist could learn about Mayan culture and traditions extraction of Manilkara Zapota or Zapote's tree resin that is a raw material to the industry of chewing gum. With uncertainty flames came intentionally or by natural issues, the true is socially people wanted to end with this noble project that could improve quality life of Chacchoben and Lazaro Cardenas' people. This work is from a point of view of residents who wanted to be in tourism activities, an example of how silence and forgotten continuing to be powerful undefeated arms and how a project failure and bad administration affects job's opportunities to local people.
\end{abstract}

Keywords: ecotourism, tourism, Thematic Park, corruption, project failure, Anthropology of tourism, Quintana Roo, Chacchoben ruins, Mayan, residents, Yucatán, Caribbean Mexican
Volume 3 Issue 2 - 2019

\author{
Ivan Carroll Janer,' Ana Isabel Buitrago \\ Garavito ${ }^{2}$ \\ 'PhD in Social Anthropology, National School of Anthropology \\ and History, Magister in Amazon Studies, National University of \\ Colombia, Colombia \\ ${ }^{2}$ Magister in History, The College of Mexico, Magister in Amazon \\ Studies National University of Colombia, Colombia
}

Correspondence: Ivan Carroll Janer, PhD in Social Anthropology, National School of Anthropology and History, Magister in Amazon Studies, National University of Colombia, Colombia, Email icarrolljaner@gmail.com

Received: June 18, 2018| Published: April 08, 2019

\section{Context}

If you were traveling by car or bus on the road Chacchoben to Merida you will see to the right a sign with the name "Pueblo Chiclero", a Thematic Park mysteriously closed. The site was strategy planning in a convergence of two points making a touristic circuit: one, Majahual cruise dock, and the other one, Chacchoben archeological site. Both were recently inaugurated, and at the same time, infrastructure was improved with roads expansion and highquality pavement. So, tourist could arrive to Majahual and have also these two cultural touristic options to visit at south state. We were informed during fieldwork that Chewing Gum Town burned and for that reason it was closed to tourist and to everybody in general even people from Chacchoben. Also, they told us front door had a padlock. During our interviews to local population, people told us Chewing Gum Town was burned. But a version of one family was difference from the version of the others. This family members, told us, it was not burned and invited us to visit it. They told us, only one palapa ${ }^{\text {ii }}$ burned but the rest of the theme park did not. At the end, we concluded people to hide corruption prefer to say it is burned. Based on Dan Sperber, ${ }^{\text {iii }}$ which talk about what socially evoke an event, our objective is to identify what does it means and evoke to local people Park Thematic burned and what are the purpose to maintain socially Thematic Park burned while physically the rest remained intact? In our information analysis process became two theories: some people said was nature, other said was intentionally. Some of them explained

\footnotetext{
iChacchoben is a Mayan word that means a place where purple corn grows.

${ }^{i i}$ A place where people could be gathered to make different activities such meeting, shopping, eat, dance, etc. It has a roof made of dried palms and wooden supports. Tourist business like this kind of architecture but is very vulnerable because fire and hurricanes end easily with this construction. iiiSee Sperber, 1991.
}

us that fire started because somebody burned trash. The problem is that fire persist for 28 days and local inconvenience avoid fire to be extinguish. Even today, talk about this topic still divided people in Chacchoben.

We arrived at front door and it did not have a padlock as people told us, so we went inside. We had a tour and we confirmed only one palapa was burned but the rest of tourist attractions were intact. This surrounding environment had a jungle which raise very fast and will disappear to a view. In which way Chacchoben and Lazaro Cardenas population relate this Thematic Park burned with its oral History and local problems? In this article, we will rebuild a history from interviews that will help us to understand social reasons to reaffirm a Thematic Park will continue burned and with a padlock.

\section{Methodology}

We applied following anthropological techniques: a) semistructured deeply interviews b) semi-structured deeply conversations c) anthropological surveys d) photographic records. Some of these tools were developed with observation-participative ${ }^{\text {iv }}$ methodology. We went to clean Chacchoben ruins with local population in order to be ready for tourists arriving.

a. Semi-structured deeply interviews with this tool we can be able to know details of oral and memory history. In most of the cases, subjects who has been interviewed, take the voice and tell us what happen.

b. Semi-structured deeply conversations: usually this tool is developed in a family context with the participation of most of the members of the family and at their own home. It is very useful

${ }^{\text {iv }}$ To know more about methodologies in anthropology see Atkinson \& Hammersley, 1994; Galindo, 1998; Peacock, 2005. 
because between them, they begin to argue about local realities and everydayness.

c. Anthropological surveys: These surveys will help to apprehend about specific topics in a shorter time. People could be interviewed when they are doing some activity for example buying something in the local store, walking to the job, seeding, sweeping, other any other activity.

d. Photographic records: This tool will help to understand everydayness of local population. It is important to clarify that every anthropological tool has a photographic record and do not have to be in a higher resolution, could be taken with a cellphone camera. We take pictures every time it is possible, but we should ask for a permission and that will make a difference with other disciplines, we should respect people privacy. Through design thinking process anthropologist could discuss what they think about a picture and this will help to understand many local social processes.

These ethnographic tools were applied to the following actors:

i. $\quad$ Tourist guides (5)

ii. Commissar and ex-commissar (5)

iii. Commissar and ex-commissars' wife (2)

iv. Empowered women (3)

v. Bus drivers (2)

vi. Taxi drivers (1)

vii. Tourists (Observation around 100 tourists)

viii. Women Artisans (3)

ix. $\quad$ Part time Chacchoben ruins employers (8)

x. Grandfather (1) and grandmother (1) (Oral history)

xi. $\quad$ Priest (1)

Total anthropological instruments: 32

During this research we have a hot summer time in 2011, living at Chacchoben with a very nice Mayan family for two months and a half between June and August, average $32-34^{\circ} \mathrm{C}$. We recorded some material, took pictures of people and each interview and surrounding areas, landscapes, ruins, etc.

This article has no intention to accuse or punish anybody because development and tourism activities must be an option not and imposition. For this reason, we are going to change names, and to give a panoramic view of what could happen in an ecotourism industry. Also, we must mention that we were sponsored by Instituto Nacional de Antropología e Historia -INAH, in Quintana Roo, and Escuela Nacional de Antropología e Historia-ENAH, in Mexico City. We analyzed all these records and then wrote a document of several pages that finally were socialized with local people. In this paper we present conclusions and highlights of this research. Also, we have presented during a Tourism Seminar at Instituto Politécnico Nacional in Mexico City at Graduate Tourism Program, invited by professor Napoleon Conde and Miguel Angel Adame. ${ }^{\mathrm{V}}$ We have discussed these results during this seminar between Mexican experts of Escuela de

'See Adame Cerón, 2011.
Turismo and they have agreed to be published. ${ }^{\text {vi }}$ At Escuela Nacional de Antropología e Historia I was the first professor who taught Anthropology of Tourism in 2012. At the beginning, first semester I had a minimum required student to open this course, six to be precisely. In the second semester, that I taught this optional course, they were 12 students. Ana Isabel Buitrago continued with this course until 2017, she had around 20 students interested in this other way to think tourism activities impacts. Also, most of these students focus tourism as a topic on their thesis work. Finally, teachers and universities started to pay attention of this new emphasis in Anthropology of Tourism.

\section{Some theory before start}

Mayan is not extinguished as people in general believed. This population in Chacchoben conserve language, houses life style, dressed and pre-Hispanic gastronomy. In a transcultural way, ${ }^{1}$ in the bottom of this mixed soup they have some tradition remnants as today most ethnics in the World. Mayan mixed all this tradition with modern life and technology.

Interest in tourism studies began with Sociologist in 1960 and 1970. Boorstin, ${ }^{2}$ MacCannell ${ }^{3}$ and Urry. ${ }^{4}$ Their thoughts and theory caught attention of Anthropologist because in recent years tourism activities have brought social problems, such: prostitution, drugs and displacement of local population. Some social scientific have significantly agreed, tourists bring more social problems than incomes: HIV, garbage, drugs, etc. In China between 1949 and 1976 tourism was prohibited because Maoist argument was it destroyed social identity, even tough today China is the second country in the World with a greater number of tourists per year. Napoleón Conde, Professor at School of Tourism of IPN in Mexico City mentioned during a Seminar. Conde have integrated Aristóteles Hermeneutic of 2,400 years ago, in this study, in other words, interpretation. The problem of travel and hospitality in social, economic, cultural and symbolic perspectives.

Jean-Didier Urbain ${ }^{5}$ put in context a critical view of a tourist who is traveling. Linderbg et al. ${ }^{6}$ used different models to identify which exchange can be done for residents when tourism activity arrived, this mean a project, to their territory. This model predict what local people can resist or what benefits they will have, for example, jobs, additional cars, roads, tax reductions, etc. Jamieson ${ }^{7}$ discussed new concepts in relation with tourism: sustainability, community participation, planning, impact evaluation, loading capacity, governance and others. Having in mind these new concepts researchers could elaborate a balance between negative and positive impacts because of tourism activities. He mentioned positive impacts: employment, foreign currency especially American dollars, poverty reduction and decrease in gender inequality, infrastructure and quality life. As negative impacts he mentions environmental degradation, traffic, shortage of drinking water, inappropriate buildings construction and roads, marketing of local traditions and increase in the cost of living.

In this way, it is necessary to establish a balance between negative and positive impacts, for example in Chacchoben we see a marketing and commercialization of local traditions with this Thematic Park, but

viParticipación en la mesa "La antropología social y la investigación turística" con la ponencia "Un pueblo chiclero maya: turismo y comunidad" durante el Encuentro Nacional de Investigación Turística, proyecto de investigación de Ciencia Básica titulado "Un enfoque hermenéutico del derecho y del turismo" con número de registro 219571, Instituto Politécnico Nacional de la Ciudad de México, May 24th 2017. Dirigido por el profesor Napoleón Conde. 
it was very educational idea and a remembrance of an unknown recent past activity. Some tourist came to Mexican Caribbean with an idea of a terrene paradise because of natural landscapes. This idea was inspired by Anglo-American culture that motivated Romanticism movement of XIX century. ${ }^{\text {vii }}$ Also, Ryan et al. ${ }^{8}$ argument tourists experience and satisfaction is more affectivity than cognitive, this mean, is visual and depends of shows and spectacles. They mentioned most of tourists prefer more rest than learning. In this same idea, Moscardo $\&$ Pearce, ${ }^{9}$ explain how authenticity is an important element in tourist experience that visit Thematic Parks with attractions. Umberto Eco ${ }^{10}$ in his book Apocalittici et integrati argument that integrati people value and glorify a right of leisure and rest in the world as tourism activities promote. Smith ${ }^{11}$ proposed a tension between tourists and local population.

Recently, Lopez Santillan ${ }^{12}$ won an INAH national price of best Doctoral Thesis in Social Anthropology about tourism consequence in Holbox Island in the Caribbean Mexican. Finally, Carroll Janer ${ }^{13,14}$ have written about negative impacts in Amazon tourism and how indigenous have substituted some traditional activities for make handicrafts. ${ }^{15-20}$

\section{Oral history of chacchoben}

They told us "people were focus in two economic activities: extraction of chewing gum and wood specially Caoba". To extract chewing gum people gathered in camps near to a lagoon. One camp had 25 men and one cooker woman. Most of the parents of these people we are interviewing arrived like this. A couple could organize a camp, man extracted chewing gum while his wife cooks for the rest of the men. People worked hard in this area, a little house of wood and palm tree, and in this way, everybody was focus on work. Roads construction, hurricanes and forest fire end with chewing gum extraction. $^{21-24}$

¡There were no school before! said to us. Children (only boys) for 10 years old we taught them to climb up trees and how to extract chewing gum, this extraction was a children school. People remember this forest plain of animals, like a zoo they told me, but in decade of 1950 some companies as Maderas Industrializadas de Quintana Roo-MIQROO- and FONAPE took from this estate all the valuable wood. Only, twenty years later, in middle seventies, people could take out these wood extraction companies. At the end of seventies, locust (langosta) affected us. Only in this decade of seventies this state had an agro-industrialized process. First trucks and tractors arrived at this region and a formal agriculture mechanized began and people continue with milpa but mechanized work it. People have prepared themselves to work with machinery. ${ }^{25,26}$

Even though, Chacchoben people were agreed they have received income from forest Wood, less from cattle raising, and a little part from agriculture. Before, agriculture was an important economic activity. They explained me that people from Michoacán State came here and found "Unidad Agricola de Lázaro Cárdenas", besides Ejido Chacchoben. viii At that time Federal government support and sponsored them because they came here to work in agriculture. Those who were "ejidatarios" asked us for permission for these people from Michoacán to establish here and we authorized them to stay. "It was very important for all of us", complemented one ex-commissar. They

\footnotetext{
viiSee Newmann, 1998.

viiiSee Pérez Saldivar, 2006
}

explained to us, people from here, who born here, we could say natives, always we have worked in traditional agriculture that is "milpa $a^{\text {ix }}$, we have extracted wood from the forest, and we practiced slash and burn. We focus several years in chewing gum extraction, but also, we sow pepper. Also, we occasionally hunt wild animals to complement our food diet. Lázaro Cardenas opened a path to progress, because agriculture was mechanized and all forest surrounding disappeared, tree felled, and became arable lands. In this process, some vestiges regrettably were destroyed because in that time nobody care about cultural heritage as today. ${ }^{27,28}$

First years had successfully production because federal government gave subsides but years later, government had restricted these subsides, with inconvenience that people were used to received them. Subsides restriction demanded people work and more real effort to produce and receive utilities. But other local people received subside and do not seed, instead they continually ask money through federal and state programs, as a result of a welfare State policy. In some way, reduction of State subsides motivate raise cattle, and today most of Lazaro Cardenas people are dedicated to this activity. They had inconvenience making transition to agriculture soil to cattle raising because land became with plaguing such Zacate Johnson which grows and did not allow crop development. Before cattle ranchers, we harvest carcass, sunflower, corn and tomato. ${ }^{29}$ Then, MIQROO ended concession and opened local opportunity to our people to sell wood and promote forestry extraction. At, that moment, they found an association in 1984 to control forestry exploitation. But today, tourism have changed local activities above all with Chacchoben Ruins opening. ${ }^{30}$

\section{Projects failure}

In 1975, a commissar brought with government subsides ten tractors and one truck in order to increase agriculture productivity of both ejidos, Chacchoben and Lazaro Cardenas. But at the end of its period, people neglected machine maintenance. Some parts were stolen and others, decided to make raffle. Thus, for example, a tractor ended up belonging to 15 people. This was a beginning of agriculture failure and most of the people moved away from politics and dedicated their self to cattle raising. An illusion, for me worst than an "Dutch disease $\mathrm{x}^{\text {", }}$ came out when someday a World Bank representative arrived and told people they were going to receive two million dollars to improve infrastructure to receive tourists because at Chachoben there were no hotels neither restaurants. It seems, suddenly will arrive walking around at Chacchoben people as Duane Hanson sculpture of Scottish National Gallery of Modern Art created in 1970. They were agreed with Majahual Dock and Chaccoben Archeological Site and knew tourists would arrive sooner or later and not only foreign tourist, also national Mexican tourism by roads but they had to invent some tourist attractions. ${ }^{31}$

At the beginning when archeological site was open, tourist people climbed at the top of the pyramids and we were worry about it could deteriorate. World Bank representatives said it will be an investment. The idea was to preserve the front of the Mayan-style houses and build some rooms to host 2 or 3 people per family, with the Mayan type of housing but with all the comforts inside. Also, they were improved water supply and prepared local people to promote bicycle and kayak

${ }^{i x}$ Traditional crop which combines corn and beans.

${ }^{x}$ Dutch disease is an economic concept, when a country receives international income and expends more money than they have. 
trips. One commissar exclaimed us enthusiastically, “ $i$ Chacchoben has a great tourism potential! it has 4 lagoons and five cenotes. It has 18,630 hectares which a forest permanent area correspond to 8,000 hectares and the rest are available to agriculture or raise catting. We worked with diverse institutional programs training 60 people in ceramic and wood's handicraft production, scented candles and English and Computeri courses. At the end, none paid too much attention about these World Bank proposals neither continuity these proposals. 32

\section{Rain forest concession, another touristic project failure}

Rainforest is a Park that combines nature with adventure, so it had at interview moment, 3 different places in Central America. His representative in Cancun visited Chacchoben and presented projections: first year 25,000 tourists, second year 40,000 and fifth year around 150,000 tourists. We have designated 50 hectares to other project, Chewing Gum Town, but Rain Forest wanted 1,500 hectares, and at first look we thought it was too much. Rainforest explained to commissars and ejidatarios, tourists will buy these tickets in cruisers. It will cost 75 USD and Chacchoben will receive 5\% of each ticket. This means with their projections in 5 years, Chacchoben will receive per year 562,500 USD. Rainforest compromised to hire 60 local population employees. Also, we will receive rent from stores in our territory and finally, Rainforest will pay us for rent in our territory around 20,000 USD monthly. Each cable way carried seven tourists and one tourist guide. Rainforest will pay intensive English courses of 90 days to local people. All of these was written in the agreement and they only need one signature. None of commissars or Ejido representative took a decision to signed, and then took place a hurricane and all this agreement was forgotten.

\section{Chewing gum town's history}

This Thematic Park had a noble initiative because all Ejido's members were going to be like shareholders. Four different Mexican institutions support this Thematic Park. It received money transfers from: Government State, Ejido Chacchoben, National Forestry Commission of Mexico and Ecotourism Programs to build bungalows. In this way, all members were summoned to create a society (SPR) and an official of Secretary of Finance came to Chacchoben in order that everybody could obtain a RFC that is a register to pay taxes and to insert a person in a formal economy. Only came 82 of 310 members, but they decided all 310 members will be shareholders even they did not assist on that day. Also, they explained us, "we established a commercial relation with one of the tourist transport companies ${ }^{\mathrm{xii}}$ of the region. But we received between 15 and 20 tourists per day, and we needed at least 120 tourists per day to do not lose money, because we had to pay salaries to employees". "It was very hard for us and also for this company", mentioned to us. So, "we decided to invent another tour for tourists, from Chaccoben ruins to Chewing gum in $4 \times 4$ motorbikes, but some tourists were drunk and had margaritas in their hand while were driving", sadly explained us because they were trying to have some revenue and when they found a way, tourist activities could put in risk life of some local population, for example

${ }^{x i M a j a h u a l ~ D o c k ~ o w n e r ~ d o n a t e d ~ s e v e r a l ~ c o m p u t e r s ~ t o ~ c h i l d r e n ~ o f ~ C h a c c h o b e n ~}$ xiiWe keep confidential this company name children walking on the road. "We concluded that ecotourism is very hard to develop", said us one of them.

All the commissars who were elected and people who took decisions in Chacchoben decided to designate a protected area to build a Thematic Park. One of the main purposes was to generate local employment. In that Park, "people knew what to do, because some of them knew traditional dancing, other knew how to extract chewing gum, while others could prepare local gastronomy", they told us. In that way, 40 to 60 people could be employed, and had a formal payment. They explained us, "Secretary of Tourism gave us the money, and it was money from Federal and State government". As, Chacchoben Ruins opened simultaneously with this Thematic Park, in some way, it was thinking in a mid-long term to improve quality life of local population from Chacchoben and Lazaro Cardenas. During tour, all the names of attractions were in three languages: English, Spanish and Maya. Chewing Gum Town had following tour and attractions: Tourists started tour from left. Tourist guides were available at entry to go inside with a group. Each tourist guide was in charge of 20 tourists. First attraction was three shamans crossed tourists so nothing will happen to them during tour for example such do not be bite by snakes. Then following attraction were trees that local people used as traditional medicine, for toothache, stomach-ache or ward off evil spirits. Next attraction was man called "chiclero" who climb a tree to extract a resin to make chewing gum. A tourist guide explained this process, and how a man had to climb this tree only with his foot, hands and a rope. Resin was cooked in a large pot by a woman.

Following Figure 1 is a sky view, a Theme Park Map which show different attractions that did not burn. In black color is the palapa that burn and in right bottom its zoom. Then, tourists found monkeys on the trees and they could play with them. Also, there were many bananas available, so tourists could feed them. Following, a hunter was hunting a deer and a boar while some women were cooking tortillas. Next attraction consisted in Xtabay, a mysterious woman which steals men. There were men drinking, and when they got drunk, they fought with machetes. One of them died and then Xtabay took him away. Then tourists how they buried this death body. Next, there was an attraction where tourist could observe honey bees. Same honey to sweet tourist's coffee at restaurant. Tourist could appreciate different plants of Chile and peppermint. It was a Magic Tree, called like that because it was big and with many fruits. Also, different vines naturally grow could be appreciate. Then, tourist could appreciate the beauty of an orchid. Secretary of Tourism helped a lot bringing different orchid species. At the end, an outdoor theater has been conditioned and local people danced. They bought several different expensive customs, as one of the commissars explained to us. Local people have practiced four different traditional dancing to liven up tourist experience.

The tour ended at the shopping center, which was a large palapa and was the palapa that was burned. Employees offered beverages to tourists in a rest area and they could appreciate handicraft in a great environment. In this place Secretary of Tourism allowed to sell drinks, like wine, tequila and other beverages. Also, a restaurant with different local gastronomy. Local people had built bungalows, if tourist wanted to stay. So, different actors, Secretary of Tourism and local were very enthusiastic with this entire project. They built a deep well for water supply and ecological toilets. It was an ecotourism environment. 


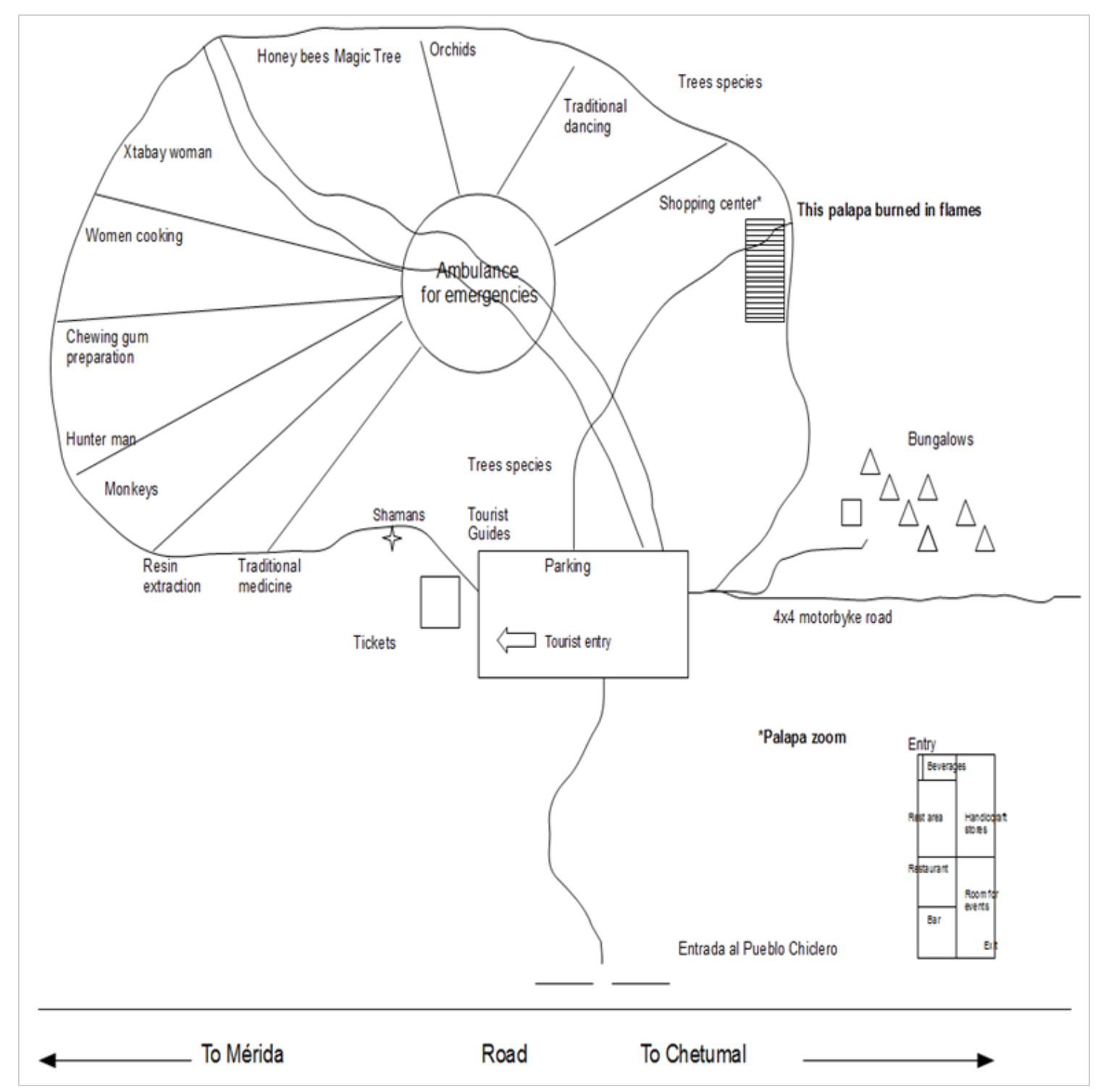

Figure I A theme park map.

\section{Conclusion}

First conclusion is that Chewing Gum Town was a Thematic Park with different attractions and not only a palapa that burned up. Some people wanted to invent a padlock in the front door and this issue has different implications. For the moment, we wanted to answer why socially wanted to be burned. In Barcelona, residents are expressing themselves with message like "stop tourist" and started to express a feeling of xenophobia against tourists, an also it is more an ecological harmed than social benefits. Technology has changed a lot of human arguments; somebody today could take a picture of something and share this picture to many people. But at that moment, this technology did not exist. Also, Chewing Gum is very far walking from Chacchoben and Lazaro Cardenas, only by car is near, and of course, not everybody in Mexico specially in Ejidos apart of big cities, have a car. So, if someone could probe a voice to voice message has to walk a great distance and then confront population with other voice to voice. In some way, this burned in a Thematic Park would not occur again, or it is not probable to happen in this way. Some people of Chacchoben saw that only a palapa burned up but we also found some of them wanted that people think that all Thematic Park were burned. It is a very sad history because silence and do not write our history is our human death. We wrote these lines because people from Chacchoben and Lazaro Cardenas have lost several jobs and opportunities and a tourism promise about improvement of life quality.

\section{Acknowledgment}

None.

\section{Conflicts of interest}

The authors declare that there is no conflict of interest. 


\section{References}

1. Ortiz Fernando. Cuban Counterpoint of the snuff and the sugar. Madrid: Chair. 2002.

2. Boorstin DJ. The Image: A Guide to Pseudo-Events in America. New York: Harper \& Row. 1964.

3. MacCannell Dean. The Tourist: a new theory of the leisure class. New York: Schocken Books. 1976.

4. Urry John. The Tourist Gaze. London: Sage. 1990.

5. Urbain Jean-Didier. The idiot who travels. Madrid: Endymion. 1993.

6. Lindberg Kreg, Tommy D Andersson, Benedict Dellaert. Tourism development. Assesing social gains and losses. Annals of Tourism Research. 2001;28(4):1010-1030.

7. Jamieson Walter. Community Destination Management in Developing Economies. New York: The Haworth Press. 2006.

8. Ryan Chris, Karen Hughes, Sharon Chirgwin. The gaze, spectacle and ecoturism. Annals of Tourism Research. 2000;27(1):148-163.

9. Moscardo Gianna, Philip L Pearce. Understanding ethnic tourists. Annals of Tourism Research. 1999;26(2):416-434.

10. Eco Umberto. Apocalyptic and integrated. Trad. Andrés Boglar. Spain: Editorial Lumen. 1984.

11. Smith Valene. Anfitriones e invitados. Madrid: Endymion. 1977.

12. López Santillán, María de los Ángeles A. Metamorphosis of paradise. The production of Holbox Island as a tourist destination in the Mexican Caribbean. Doctoral Thesis in Social Anthropology at El Colegio de Michoacán, Center for Anthropological Studies. Michoacán. 2010.

13. Carroll Janer Ivan. The illusion of tourism. Notimani National University of Colombia Amazonia Headquarters. 2012;(24):25-26.

14. Carroll Janer Ivan. Crafts, traditions and representations. Notimani National University of Colombia Amazonia Headquarters. 2015(29):12-13.

15. Adame Cerón, Miguel Ángel. Anthropology of meetings and tourist impacts in the communities. Mexico City: Navarra Editions. 2011.

16. Atkinson Paul, Martyn Hammersley. Ethnography: Research Methods. Barcelona: Paidós. 1994.

17. Clancy Michael. Tourism and Development. Evidence from Mexico. Annals of Tourism Research. 1999;26(1):1-20.

18. Clancy Michael. The Globalization of Sex Tourism and Cuba: A Commodity Chains Approach. Studies in Comparative International Development. 2002;36(4):63-88.
19. Del Ángel Pavel. Dispossession and illusions. Tourism and development in Punta de Mita south coast of Nayarit. Thesis of Degree in Social Anthropology at the National School of Anthropology and History. Mexico. 2005.

20. Duarte Duarte, Ana Rosa, Byrt Wammack Weber. Leisure spaces: deciphering the Mayan Riviera "in Gender in the era of globalization. Looks from the Mayan world, Mexico: Autonomous University of Yucatán, Eastern University, Plaza \& Valdés. 2010;53-99.

21. Escalante Gonzalbo, María de la Paloma, Ivan Enrique Carroll. Anthropology and Tourism. Cuicuilco. 2013;20(56):249-259.

22. Galindo Cáceres, Luis Jesús. Etnografia The office of the look and the sense. In: Galindo Cáceres, Luis Jesús (Coord.) Research techniques in society, culture and communication. México: Addison Wesley Longman. $1998 ; 347-383$

23. McLaren D. Rethinking Tourism and Ecotravel: The Paving of Paradise and What you can do to stop it. West Hartford: Kumarian. 1997.

24. Nash Dennison. Anthropology of Tourism. New York: Pergamon. 1996.

25. Newmann Roderick. Imposing Wilderness. Strugles over livehood and nature preservation in Africa. Los Angeles: University of California Press. 1998.

26. Peacock James. The Anthropological lens. Madrid: Editorial Alliance. 2005.

27. Pérez Beatriz. Tourism and representation of culture: cultural identity and resistance in Andean communities of Cusco. Anthropological. 2006;XXIV(24):29-49.

28. Pérez Zaldívar, Juan Salvador. Ecotourism and family organization in two communities in the south of the state of Quintana Roo: Chacchoben and Lázaro Cárdenas. Thesis to obtain Degree in Anthropology. Chetumal: University of Quintana Roo. 2006.

29. Rossel P. Tourism: Manufacturing the Exotic. Copenhagen: IWGIA. 1988.

30. Sperber Dan. Interpretive ethnography and theoretical anthropology. Alterities. 1985;1(1):111-128.

31. Stronza Amanda. Anthropology of tourism: Forging new ground for ecotourism and other alternatives. Annual Review of Anthropology. 2001;30:261-83

32. Van der Bergue, Pierre L, Jorge Flores Ochoa. Tourism and Nativistic Ideology in Cuzco, Peru. Annals of Tourism Research. 2000;27(1):7-26. 